\title{
Molecular detection of Candidatus Anaplasma camelii in camels (Camelus dromedarius) from Asir Province, Saudi Arabia
}

\author{
Alshahrani, M.Y. ${ }^{1}$, Alanazi, A.D. ${ }^{2 *}$, Alouffi, A.S. ${ }^{3}$, Abdullah, H.H.A.M. ${ }^{4}$, Allam, A.M. ${ }^{4}$, Mahmoud, M.S. ${ }^{4}$, \\ Abdel-Shafy, S. ${ }^{4}$, Alfaifi, M.H. ${ }^{1}$ and Alkhathami, A.G. ${ }^{1}$ \\ ${ }^{1}$ Department of Clinical Laboratory Sciences, College of Applied Medical Sciences, King Khalid University, \\ P.O. Box 61413, Abha, 9088, Saudi Arabia \\ ${ }^{2}$ Department of Biological Sciences, Faculty of Science and Humanities, Shaqra University, P.O. Box 1040, \\ Ad-Dawadimi 11911, Saudi Arabia \\ ${ }^{3}$ King Abdulaziz City for Science and Technology, Riyadh, Saudi Arabia \\ ${ }^{4}$ Department of Parasitology and Animal Diseases, Veterinary Research Division, National Research Centre, \\ 33 Bohouth St., Dokki, 12622 Giza, Egypt \\ *Corresponding author e-mail: aalanazi@su.edu.sa \\ Received 30 January 2020; received in revised form 8 April 2020; accepted 9 April 2020
}

\begin{abstract}
Knowledge of molecular identification of tick-borne pathogens in camels in Saudi Arabia is very limited; few molecular epidemiological studies have been under taken. This study was to detect Anaplasma spp. and Piroplasma spp. in camels from Asir Province, Saudi Arabia. A total of 150 blood samples were collected from camels in Asir Province and investigated by polymerase chain reaction (PCR) that targeted $18 \mathrm{~S}$ rRNA and $23 \mathrm{~S}$ rRNA to detect the DNA of Piroplasma spp. and Anaplasma spp., respectively. The positive samples for $23 \mathrm{~S}$ rRNA were assayed again by PCR targeting the 16S rRNA. All the blood samples were free from Piroplasma spp. infection. Three camels (2\%) were found to be positive for Anaplasma infection through use of PCR that targeted the 23S rRNA gene. There were no significant differences between ages or sexes in the camels that tested positive for Anaplasma. All positive Anaplasma infections were recorded in camels that were infested by ticks. Two Anaplasma sequences for the16S rRNA gene were deposited in GenBank with accession numbers MN882724 and MN882725. They recorded $99.16 \%$ and $99.34 \%$ similarities (respectively) with KF843825.1 (Candidatus Anaplasma camelii reported in Unizah, Saudi Arabia). Phylogenetic analyses revealed that the two sequences recorded in this study were close to each other; both were located in one cluster with Candidatus Anaplasma camelii isolates that were recorded before in the adjacent areas of Unizah in Saudi Arabia and Iran. In conclusion: two new Anaplasma genotypes close to Candidatus Anaplasma camelii were found in camels in Asir Province, Saudi Arabia for the first time. The camels in this province were found to be free of Piroplasma infection.
\end{abstract}

\section{INTRODUCTION}

Arthropods such as ticks, fleas and mosquitoes are globally important vectors of a wide range of viral, bacterial and protozoal pathogens that result in a wide range of vector-borne diseases (Otranto and Dantas-Torres, 2010). Vector-borne diseases are both emerging and re-emerging, and they pose a direct threat to human health and animal welfare (Yuasa et al., 2012; de La
Fuente $e t a l ., 2017)$. In addition to acting as vectors, ticks also affect the well being of their hosts directly through irritating bites, blood loss, damage to the skin and anorexia that leads to reduced growth (Jabbar et al., 2015).

Piroplasmosis and Anaplasmosis are tick-borne diseases that are globally distributed and negatively affect animal production (de La Fuente et al., 2017). These diseases infect a wide range of animals, 
especially ruminants, which include camels. The diseases cause fever, anaemia, weakness, lethargy and death in acute cases (Otranto and Dantas-Torres, 2010).

In Saudi Arabia, the livestock sector in 2015 contributed $2.7 \%$ to the country's Gross Domestic Product (GDP) (General Authority for Statistics, 2015). Saudi Arabia is listed among the countries that show strong recent growth in the camel population; in 2016, the country had a population of approximately one million camels, with the highest percentage in Riyadh Province (General Authority for Statistics, 2016). In addition, thousands of live camels are imported annually from neighbouring countries such as Somalia, Egypt, Sudan and Arabian Gulf countries (General Authority for Statistics, 2016). Many rural communities are dependent on these animal species for their livelihoods, since camels and cattle are a good source of meat, milk and leather (Elzaki et al., 2018; Redwan et al., 2018).

Camel production is severely affected by various diseases and in adequate veterinary services (Bekele, 2010). Several endo-and ectoparasites affect their health, productivity and performance, including ticks (Bekele, 2010). The feeding activity of ticks causes blood loss and anaemia, and the ticks transmit various disease pathogens to humans (Orkun et al., 2014). Ticks can cause irritation, inflammation, hypersensitivity and damage to the animal hides, leading to production losses (Wall and Shearer, 2001).

Previous studies on ticks in Saudi Arabia have shown that there are more than 20 ixodid species and subspecies that infest domestic animals including camels (Hoogstraal et al., 1981; Al-Khalifa and Diab, 1986, Alanazi et al., 2019). However, knowledge of molecular identification of tick-borne pathogens in domestic animals including camels in Saudi Arabia is very limited, since few molecular epidemiological studies have been undertaken (Alanazi et al., 2014; Ismael et al., 2014; Mohammed et al., 2017; Alanazi et al., 2018; Salim et al., 2019; Alanazi et al., 2020). Therefore, the aim of this study was to detect Anaplasma spp. and Piroplasma spp. in camels from Asir Province, Saudi Arabia.

\section{MATERIALS AND METHODS}

\section{Ethical approval}

This study was revised and approved by the Ethical Research Committee, Deanship of Scientific Research, King Khalid University, according to the ethical principles of human and animal research (Approval no. (ECM\#2019-74)-(HAPO-06-B-001).

\section{Study site}

Asir Province has an area of 76,690 $\mathrm{km}^{2}$ and is located in the southwestern part of Saudi Arabia between $19^{\circ} 02 \mathrm{~N}$ and $43^{\circ} 02 \mathrm{E}$ (Figure 1). The province is situated on a high plateau that receives more rainfall than the rest of the country and contains the country's highest peaks, which rise to almost 3,000 m. Asir has a tropical and subtropical climate and the average annual rainfall in the highlands ranges from $300 \mathrm{ml}$ to $500 \mathrm{ml}$. It has two rainy seasons. As a result, there is much more natural vegetation and forests than the rest of Saudi Arabia (http://www. pme.gov.sa).

\section{Collection of camel blood samples and DNA isolations}

The cross-sectional study was conducted from August 2019 to Junary 2020 in Asir Province of Saudi Arabia. Blood samples were collected from 150 camels of both sexes and age groups; camels were selected at random. The camels ranged in age from $<1$ year to $>15$ years. Blood samples were collected from each animal (2-8 ml) from the cephalic vein into vacutainer tubes with EDTA (BD Vacutainer ${ }^{\circledR}$ Tube, Gribbles Pathology, VIC, Australia) and transported in an ice box to the parasitology laboratory at the Department of Biological Sciences, Faculty of Science and Humanities, Shaqra University, for DNA extraction. Total genomic DNA (gDNA) was isolated from the blood samples using the Wizard ${ }^{\circledR}$ Genomic DNA Purification Kit (Promega, Madison, WI, USA) and eluted in $50 \mu \mathrm{l}$ or $100 \mu \mathrm{l}$ of elution buffer 


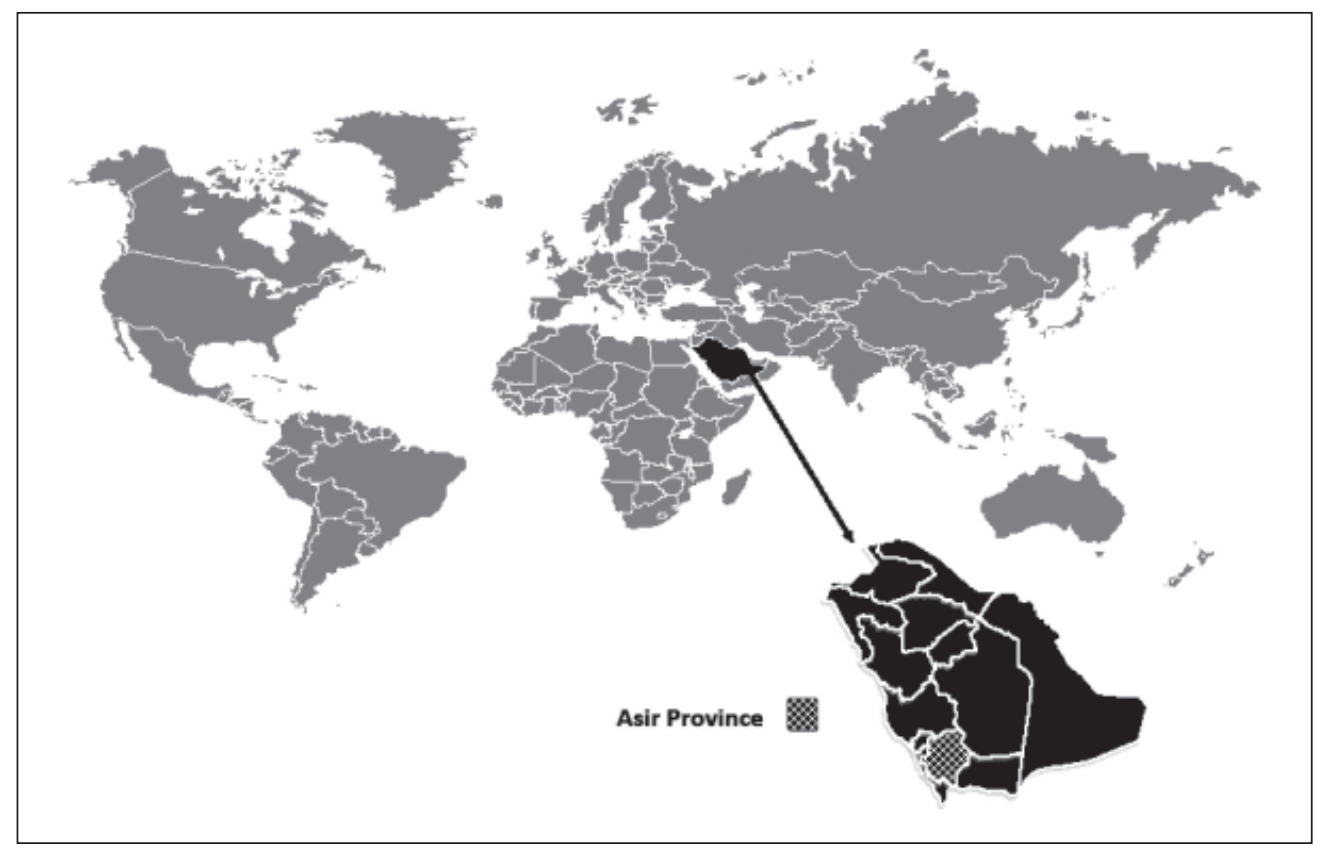

Figure 1. Map showing the location of the study site in Saudi Arabia.

Table 1. Oligonucleotide sequences of primers used for PCR and sequencing in this study

\begin{tabular}{|c|c|c|c|c|c|}
\hline Parasite & $\begin{array}{l}\text { Targeted } \\
\text { gene }\end{array}$ & Name & Primers & $\begin{array}{c}\text { Fragment } \\
\text { length } \\
\text { (bp) }\end{array}$ & Reference \\
\hline \multirow{2}{*}{ Piroplasma } & \multirow{2}{*}{ 18S RNA } & piro18S-F1 & GCGAATGGCTCATTAIAACA & \multirow{2}{*}{1100} & \multirow{2}{*}{$\begin{array}{l}\text { Dahmana } \\
\text { et al., } 2019\end{array}$} \\
\hline & & piro18S-F4 & CACATCTAAGGAAGGCAGCA & & \\
\hline \multirow{4}{*}{ Anaplasmataceae } & \multirow{2}{*}{ 23S RNA } & Ana23S-212f & ATAAGCTGCGGGGAGTTGTC & \multirow{2}{*}{500} & \multirow{2}{*}{$\begin{array}{l}\text { Dahmani } \\
\text { et al., } 2017\end{array}$} \\
\hline & & Ana23S-753r & TGCAAAAGGTACGCTGTCAC & & \\
\hline & \multirow{2}{*}{ 16S rRNA } & ECB & CGTATTACCGCGGCTGCTGGCA ${ }^{\mathrm{a}}$ & \multirow{2}{*}{500} & \multirow{2}{*}{$\begin{array}{l}\text { Rufino et } \\
\text { al., } 2013\end{array}$} \\
\hline & & ECC & AGAACGAACGCTGGCGGCAAGCa & & \\
\hline
\end{tabular}

as per the manufacturer's instruction. An aliquot of between $50 \mu \mathrm{l}$ and $100 \mu \mathrm{l}$ of gDNA from each sample was stored at $-20^{\circ} \mathrm{C}$ prior to molecular analysis.

\section{PCR protocol}

The primers were designed to targeta $969 \mathrm{bp}$ section of the conserved region that encoded for the18S rRNA gene and a 485 bp section that encoded for the 23S rRNA gene to detect the DNA of Piroplasma (Dahmana et al., 2019) and Anaplasma (Dahmani et al., 2017) respectively (Table 1). The positive samples for Anaplasma were assayed again by polymerase chain reaction (PCR), targeting the 16S rRNA gene (Rufino et al., 2013). PCR assays were performed in automated BIORAD Thermal Cycler (BIO-RAD, Singapore) using One PCR master mix ${ }^{\mathrm{TM}}$ (GeneDireX, Taiwan). The PCR conditions for the Piroplasma amplification were: one incubation step at $95^{\circ} \mathrm{C}$ for $15 \mathrm{~min}$; 35 cycles of $1 \mathrm{~min}$ at $95^{\circ} \mathrm{C} ; 30 \mathrm{~s}$ of annealing at $58^{\circ} \mathrm{C}$ and 1 min at $72^{\circ} \mathrm{C}$; followed by a final 
extension for $5 \mathrm{~min}$ at $72^{\circ} \mathrm{C}$. Positive and negative controls were included. The PCR conditions for Anaplasma amplification that targeted the 23S rRNA gene were: an initial denaturation step at $95^{\circ} \mathrm{C}$ for $15 \mathrm{~min}$; followed by 40 cycles that consisted of 1 min denaturation at $95^{\circ} \mathrm{C}, 1 \mathrm{~min}$ annealing at $55^{\circ} \mathrm{C}$, a 1 min extension at $72^{\circ} \mathrm{C}$ and a final extension cycle at $72^{\circ} \mathrm{C}$ for $7 \mathrm{~min}$; and the reactions were cooled at $15^{\circ} \mathrm{C}$. The PCR conditions of Anaplasma amplification targeting the 16S rRNA gene were: initial denaturation at $95^{\circ} \mathrm{C}$ for $5 \mathrm{~min}$; followed by 35 cycles of denaturation at $95^{\circ} \mathrm{C}$ for $30 \mathrm{~s}$; annealing and extension at $65^{\circ} \mathrm{C}$ for $30 \mathrm{~s} ; 10$ cycles of $62^{\circ} \mathrm{C}$ for $30 \mathrm{~s}$; and final extension at $72^{\circ} \mathrm{C}$ for $30 \mathrm{~s}$. After the last cycle, the extension step was continued for a further 5 min. Distilled water was used as the negative control. Positive controls were the DNA of Theileria annulata extracted from cattle and Anaplasma marginale extracted from cattle for PCR assays of Piroplasma and Anaplasma, respectively. Then, the amplifications were confirmed by electrophoresis on a 1.5\% agarose gel, stained with Red Safe and examined by UV transillumination. A DNA molecular-weight marker (100bp DNA Ladder H3 RTU, GeneDireX, Taiwan) was used to estimate the size of the products. The PCR products of the positive samples were purified by using PCR Clean-Up \& Gel Extraction Kit (GeneDireX, Taiwan) according to the manufacturer's instructions.

\section{Sequencing and phylogenetic analyses}

The purified PCR products were sequenced at Macrogene Lab Technology, Korea. The obtained sequences were assembled using ChromasPro software (ChromasPro 1.7, Technelysium Pty Ltd., Tewantin, Australia). The obtained sequences were submitted to GenBank and then compared with those available in the GenBank database by the National Center for Biotechnology Information (NCBI) Basic Local Alignment Search Tool (BLAST) (http://blast.ncbi.nlm.nih.gov/ Blast.cgi). The sequences that were obtained from positive samples were aligned with sequences of validated species already available in GenBank using Bioedit software version 7.0.5.3 (Clustal W multiple alignment) (Hall, 2011). For taxonomic analyses, the maximum-likelihood phylogenetic trees were constructed using MEGA software version X (Kumar et al., 2018) with 500 bootstrap replications.

\section{Statistical analysis}

The significant differences between genders and ages of camels infected with Anaplasma were calculated by $\chi^{2}$ test using the SPSS program (version 20.0) at $P<0.05$.

\section{RESULTS}

\section{Anaplasma infection}

Three out of 150 camels (2\%) in Asir Province were positive for Anaplasma infection as shown by PCR that targeted the 23S rRNA (Table 2). The risk factors that are associated with Anaplasma infections were detected by PCR in camels in the same place (Table 3). There were no significant differences between ages or sexes of the camels that tested positive for Anaplasma. Two camels that were more than one year old and one that was one year old were infected with Anaplasma. Of these, two were female and one male. Furthermore, all positive Anaplasma infections were recorded in camels infested by ticks, while all animals uninfested by ticks were free of any Anaplasma infection.

The samples that were positive for Anaplasma infection showed the $520 \mathrm{bp}$ band in the amplification of the 23S rRNA. Two out of three of the Anaplasma samples that were positive in the 23S rRNA amplification revealed a strong $500 \mathrm{bp}$ band for the 16S rRNA (Figure 2). These two positive samples for Anaplasma infection for the $16 \mathrm{~S}$ rRNA gene were sequenced

Table 2. Prevalence of Piroplasma and Anaplasma detected by PCR in camels in Asir Province, Saudi Arabia

\begin{tabular}{cccccc}
\hline \multirow{2}{*}{$\begin{array}{c}\text { Examined } \\
\text { camels }\end{array}$} & \multicolumn{2}{l}{ Piroplasma } & spp. & & \multicolumn{2}{c}{ Anaplasma spp. } \\
\cline { 2 - 3 } & Positive & $\%$ & & Positive & $\%$ \\
\hline 150 & 0 & 0 & & 3 & 2.00 \\
\hline
\end{tabular}


Table 3. Risk factors associated with Anaplasma infections detected by PCR in camels in Asir Province, Saudi Arabia

\begin{tabular}{|c|c|c|c|c|}
\hline \multirow{2}{*}{\multicolumn{2}{|c|}{ Factor }} & \multirow{2}{*}{$\begin{array}{l}\text { Total number } \\
\text { of camels }\end{array}$} & \multicolumn{2}{|c|}{ Anaplasma spp. } \\
\hline & & & Positive & $\%$ \\
\hline \multirow{4}{*}{ Age (year) } & $\leq 1$ & 28 & 1 & 3.57 \\
\hline & $>1$ & 122 & 2 & 1.64 \\
\hline & $\chi^{2}$ & & \multicolumn{2}{|c|}{0.333} \\
\hline & Sig. & & \multicolumn{2}{|c|}{ NS } \\
\hline \multirow{4}{*}{ Gender } & Male & 52 & 1 & 1.92 \\
\hline & Female & 98 & 2 & 2.04 \\
\hline & $\chi^{2}$ & & \multicolumn{2}{|c|}{0.333} \\
\hline & Sig. & & \multicolumn{2}{|c|}{ NS } \\
\hline \multirow{2}{*}{ Ticks } & Yes & 127 & 3 & 2.36 \\
\hline & No & 23 & 0 & 0 \\
\hline
\end{tabular}

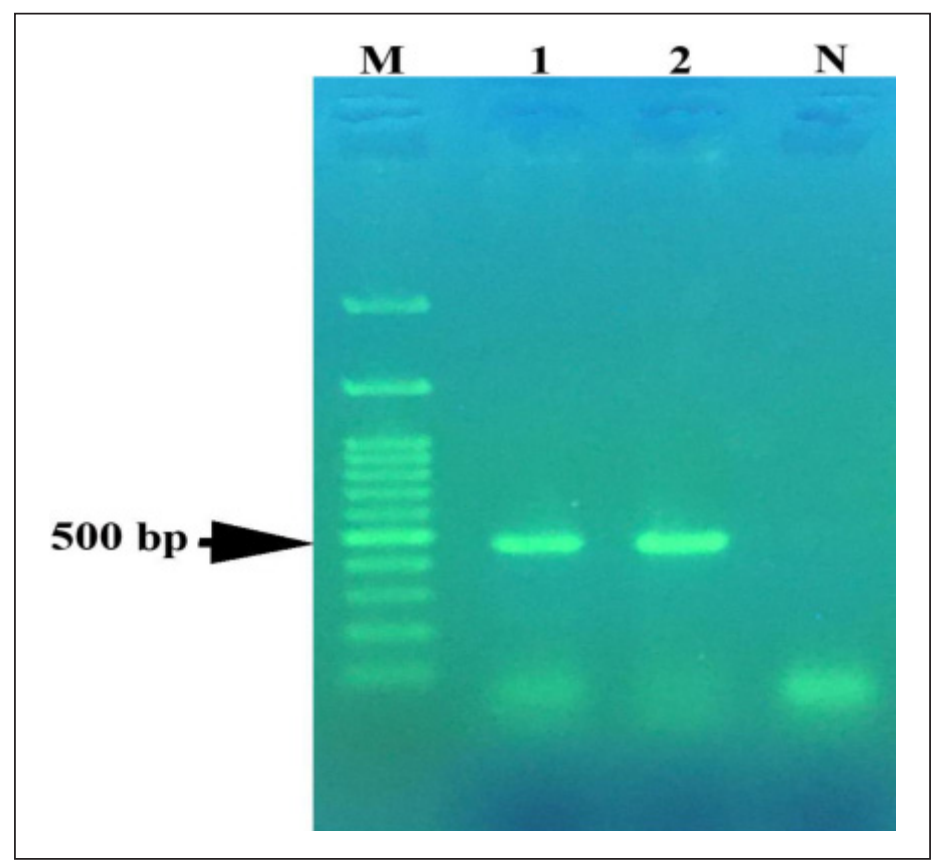

Figure 2. Image of agarose gel electrophoresis (1.5\%) showing $500 \mathrm{bp}$ band for the amplification of 16S rRNA gene of Anaplasma. Lane M: DL 2000 marker; Lane N: negative control; Lanes 1-2: positive samples.

and recorded in GenBank with accession numbers MN882724 and MN882725. The accession number MN882724 has been named as Anaplasma camelii AC119 camel blood Saudi Arabia and recorded similarities of $99.16 \%, 98.74 \%$ and $98.32 \%$ with the previous accession numbers KF843825.1 (Candidatus Anaplasma camelii in Unizah, 
Saudi Arabia covering 100\%), MF289478.1 (Anaplasma platys isolate in China covering 100\%) and MK814419.1 (Anaplasma platys isolate in South Africa covering 100\%), respectively. The accession number MN882725 has been named as Anaplasma camelii AC103 camel blood Saudi Arabia and recorded similarities of $99.34 \%$, $98.89 \%$ and $98.4 \%$ with the previous accession numbers KF843825.1 (Candidatus Anaplasma camelii in Unizah, Saudi Arabia covering 100\%), MF289478.1 (Anaplasma platys isolate in China covering 100\%) and MK814419.1 (Anaplasma platys isolate in South Africa covering 100\%), respectively.
A phylogenetic tree revealed that the two genotypes recorded in this study were close to each other and that both were located in one cluster with Candidatus Anaplasma camelii isolates that had been previously recorded in adjacent areas such as Unizah, Saudi Arabia and Iran (Figure 3).

\section{Piroplasma infection}

A total of 150 camels were screened by PCR that targeted the18S RNA gene for the presence of Piroplasma infection in Asir Province, Saudi Arabia. All camel blood samples were found to be negative for Piroplasma infection.

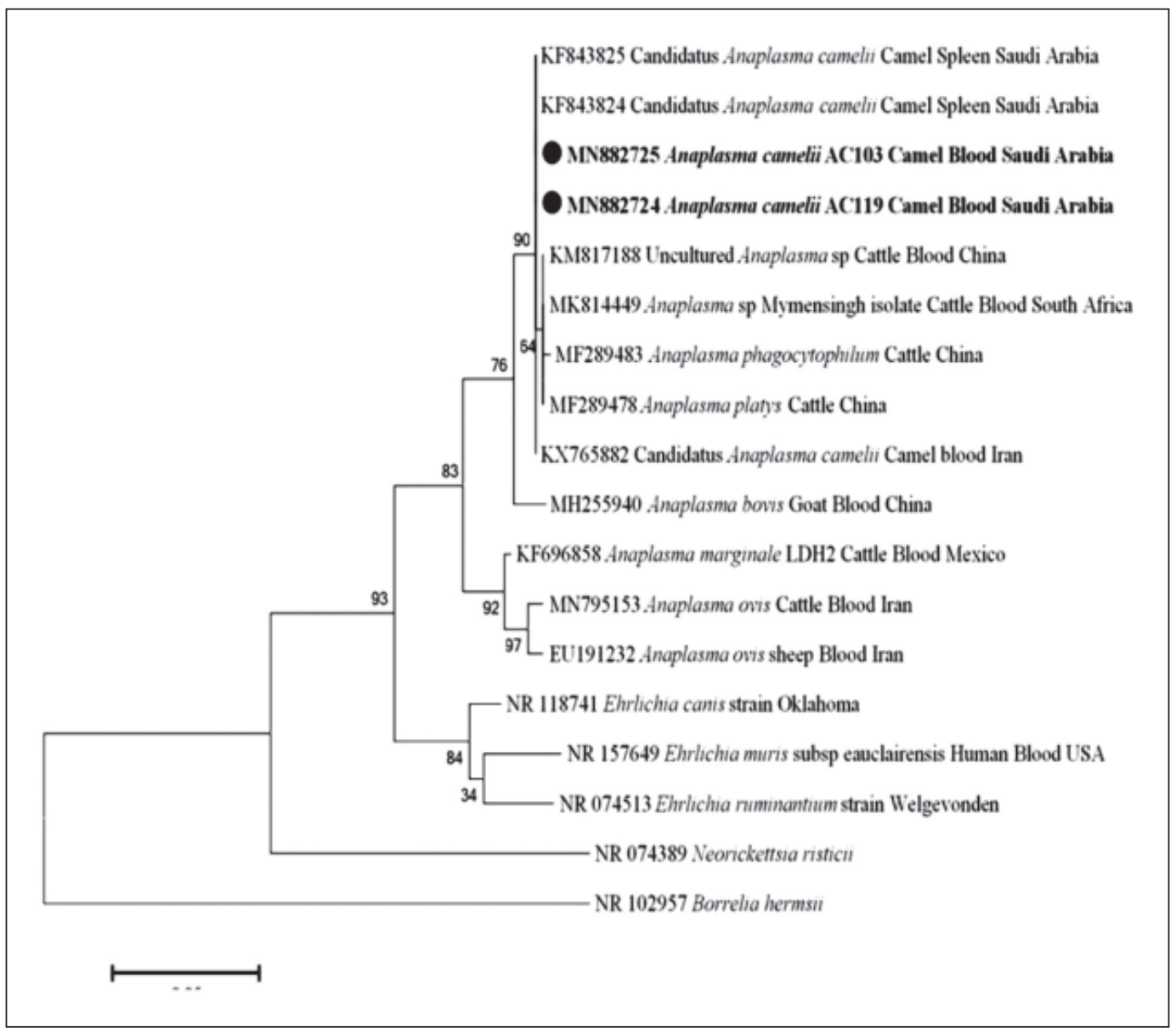

Figure 3. 16S rRNA-based phylogenetic analysis of genotypes identified in this study. Phylogenetic tree highlighting the position of Anaplasma sp. in the present study (bold) related to other Anaplasma sp. available in GenBank. The sequences of 16S rRNA were aligned using CLUSTAL W and phylogenetic inferences were constructed in MEGA X using Maximum Likelihood based on Tamura-Neimodel for nucleotide sequences with 500 bootstrap replicates. There was a total of 509 positions in the final dataset. The scale bar represents a $5 \%$ nucleotide sequence divergence. 


\section{DISCUSSION}

Tick-borne pathogens such as Piroplasma (Babesia and Theileria) and Anaplasma (Anaplasma and Ehrlichia) have an economic importance regarding ruminants such as camels. Recently, many studies have used molecular tools to screen and identify these pathogens worldwide in camel hosts and their tick vectors (Mazyad and Khalaf, 2002; Sloboda et al., 2011; Qablan et al., 2012; Belkahia et al., 2015; Khamesipour et al., 2015; Li et al., 2015; Lorusso et al., 2016; Ait Lbacha et al., 2017; Alsarraf et al., 2017; Sharifiyazdi et al., 2017; Azmat et al., 2018; Bahrami et al., 2018; Noaman, 2018; Azeem et al., 2019; Sazmand et al., 2019; Selmi et al., 2019; Selmi et al., 2020). In Saudi Arabia, very few studies concerned with these pathogens in camels have been performed (Al-Khalifa et al., 2009; Ghafar and Shobrak, 2014; Mostafa and Dajem, 2014; Bastos et al., 2015; Alanazi et al., 2018; Alanazi et al., 2020). Al-Khalifa et al. (2009) found that camels in the Asir region were free from blood parasites. Mostafa and Dajem (2014) found Babesia bovis in camels. In the Taif region, Ghafar and Shobrak (2014) showed that camels were free from Anaplasma phagocytophilum. Bastos et al. (2015) recorded novel genotypes most closely related to Anaplasma platys in the Unizah region. Alanazi et al. (2018) found that one Hyalomma dromedarii tick collected from a camel in Riyadh Province tested positive for Theileria sp. DNA. Alanazi et al. (2020) reported several pathogens (e.g. Anaplasma platys, Anaplasma phagocytophilum, Anaplasma sp., Ehrlichia canis and Hepatozoon canis) in camels from Riyadh Province.

In spite of a unique study that was conducted in the Asir region by Al-Khalifa et al. (2009), who indicated that the camels in this region were free of blood parasites, we believed that tick-borne pathogens might be found because most animals were found to be infested by ticks (127/150). Therefore, the goal of this study was to perform a trial to discover the presence of Piroplasma and Anaplasma in blood samples of camels in the Asir region, using two pairs of primers that belonged to the $18 \mathrm{~S}$ and $23 \mathrm{~S}$ rRNA genes, respectively, in addition to a pair of primers that belonged to the $16 \mathrm{~S}$ rRNA gene. The latter was used in sequencing of Anaplasma that were positive for $23 \mathrm{~S}$ rRNA due to a failure to obtain sequencing from PCR products that resulted from 23S rRNA.

The present study revealed that all camels tested were found to be free from Piroplasma infection which is in agreement with finding of Alanazi et al. (2020). This finding might be attribute to isolation of the locality from Piroplasma infection or to the animals having been treated against Piroplasma. In disagreement with the results of the present study, Selmi et al. (2019) found Babesia spp. infection (1.0\%) for the first time in Tunisia, in one adult female camel that under went abortion and was anaemic. In Pakistan, Azeem et al. (2019) found Babesia and Anaplasma in 3\% of camels, but this percentage was not accurate because the researchers used a staining procedure in their investigation. Li et al. (2019) obtained 18S rRNA and major piroplasm surface protein (MPSP) gene sequences of Theileria sinensis from Bactrian camels and ticks in Xinjiang, China. In Iran, Bahrami et al. (2017) investigated 248 camels for Piroplasma infection by $18 \mathrm{~S}$ rRNA sequencing; they found that three and seven camels were infected with Babesia caballi and Theileria equi, respectively. These infections may be attributed to the presence of equines that lived with the camels; the same equine Piroplasma infection was found in camels in Jordan by Qablan et al. (2012). In Nigeria, Lorusso et al. (2016) detected A. platys and T. ovis in camels.

The present study is considered to be the first report that has recorded Anaplasma in Asir Province, Saudi Arabia, by use of PCR targeting the 23S rRNA. Moreover, this study has recorded two new genotypes related to Canditatus Anaplasma camelii with similarity of $99 \%$ for the first time. The sequences of these two genotypes were obtained from PCR products of the 16S rRNA gene and deposited in GenBank 
with accession numbers MN882724 and MN882725. Three of 150 camels (2\%) were found to be positive for Anaplasmosis in Asir Provonce. This level of infectionis lower than that recorded in the Taif and Unizah regions of Saudi Arabia by Ghafar and Shobrak (2014) and Bastos et al. (2015), who recorded more than $30 \%$ infection in camels. The high infection rates reported in these two studies may be due to the small sample sizes or the geographical locations.

Recently, Anaplasmosis was studied by molecular detection in camels of areas that surround Saudi Arabia in countries such as Iran, Tunisia, Morocco, Pakistan and China. All these studies recorded Anaplasma infection in camels at levels that were higher than those recorded in the current study, except for a unique study conducted in Tunisia by Selmi et al. (2020). This study found $A$. ovis in $1.2 \%$ of camels when the researchers investigated 412 camels for Anaplasmosis using PCR and sequencing that targeted the groEL and msp 4 genes. However, in Tunisia, Selmi et al. (2019) found A. platys-like strains in 5.6\% (23/412) of camels by use of a PCR/restriction fragment length polymorphism assay, and Belkahia et al. (2015) found Anaplasma spp. DNA of the 16S rRNA gene in $17.7 \%$ of 226 camels. In studies of camels in Iran, Sharifiyazdi et al. (2017), Bahrami et al. (2018) and Sazmand et al. (2019) recorded $6 \%$ (6/100) infection by A. platys, $34.2 \%$ (71/207) infection by $A$. phagocytophilum and 15\% (30/200) infection by Candidatus Anaplasmac amelii, respectively. In Pakistan, Azmat et al. (2018) found an overall 13.33\% prevalence of Anaplasmosis in camels. In Morocco, Ait Lbacha et al. (2017) recorded that $39.62 \%$ of their camel sample (42/106) were positive for Anaplasmataceae spp. In China, Li et al. (2015) found that 7.2\% (20/ 279 ) of the camels harboured $A$. platys DNA.

The phylogenetic tree of the genotypes obtained in the present study indicated that our genotypes were located in one cluster with Candidatus Anaplasma camelii isolates that had been previously recorded in Unizah, Saudi Arabia, (Bastos et al., 2015) and in Iran (Sazmand et al., 2019). This finding suggests that these new genotypes of Anaplasma circulate in Saudi Arabia and adjacent countries. The Anaplasma spp. in camels in other countries were discovered using different genes from those used in this study. For example, in Tunisia, Selmi et al. (2020) used groEL and $m s p 4$ genes to identify Anaplasma ovis in camels; and in Morocco, Ait Lbacha et al. (2017) used the groEL gene in detection of Candidatus Anaplasma camelii in camels. Therefore, further extensive research that involves a large number of camels is needed in Saudi Arabian provinces to confirm the identification of Anaplasma spp. in camels in Saudi Arabia.

\section{CONCLUSION}

Two new Anaplasma genotypes close to Candidatus Anaplasma camelii were reported for the first time in camels from Asir Province, Saudi Arabia. The camels in this province were found to be free from Piroplasmosis. Therefore, it is recommended that a large number of animals in different provinces should be investigated through use of different genes to confirm Piroplasma infection in camels in Saudi Arabia.

\section{DISCLOSURE}

The authors declare that they have no competing interests.

\section{FUNDING}

This project was supported by the Deanship of Scientific Research, King Khalid University, under grant number (G.R.P-287-40).

\section{AUTHORS' CONTRIBUTIONS}

All authors shared in the design of the plan of this study. MYA, ADA, ASA, MA and AGA collected blood samples from camels and extracted DNA from the blood samples. ADA, HHAMA, AMA and SA participated in the conduction of PCR protocols, purification of PCR products, sequence analyses, construction of the phylogenetic tree and analysis of the data. ADA, SA, HHAMA and AMA shared in writing the manuscript. All authors revised and approved the final version of the manuscript. 
Acknowledgements. This study was kindly supported by King Khalid University and Shaqra University, Deanship of Scientific Research. The authors extend their appreciation to the Deanship of Scientific Research at King Khalid University for funding this work through the Research Group Projects under grant number (R.G.P2/78/40). The authors also would like to thank the staff members of Department of Parasitology and Animal Diseases, Veterinary Research Division, National Reserche Center, Egypt.

\section{REFERENCES}

Al-Khalifa, M. \& Diab, F. (1986). A checklist of ticks (Acari: Ixodidae) infesting local farm animals in Saudi Arabia. II. Ticks of Riyadh province. Journal of College Science, King Saud University 17: 151157.

Al-Khalifa, M.S., Hussein, H.S., Diab, F.M. \& Khalil, G.M. (2009). Blood parasites of livestock in certain Regions in Saudi Arabia. Saudi Journal of Biological Sciences 16(2): 63-67.

Alanazi, A.D., Abdullah, S., Helps, C., Wall, R., Puschendorf, R., Al-Harbi, S.A., AbdelShafy, S. \& Shaapan, R.M. (2018). TickBorne Pathogens in Ticks and Blood Samples Collected from Camels in Riyadh Province, Saudi Arabia. International Jourmal of Zoological Research 14: 30-36.

Alanazi, A.D., Al-Mohammed, H.I., Alyousif, M.S., Said, A.E., Salim, B., Abdel-Shafy, S. \& Shaapan, R.M. (2019). Species Diversity and Seasonal Distribution of Hard Ticks (Acari: Ixodidae) Infesting Mammalian Hosts in Various Districts of Riyadh Province, Saudi Arabia. Journal of Medical Entomology 56: 1027-1032.

Alanazi, A.D., Said, A.E., Morin-Adeline, V., Alyousif, M.S. \& Šlapeta, J. (2014). Quantitative PCR detection of Theileria equi using laboratory workflows to detect asymptomatic persistently infected horses. Veterinary Parasitology 15(3-4): 138-145.
Alanazi, A.D., Nguyen, V.L., Alyousif, M.S., Manoj, R.R., Alouffi, A.S., Donato, R. Sazmand, A., Mendoza-Roldan, J.A., Dantas-Torres, F. \& Otranto, D. (2020). Ticks and associated pathogens in camels (Camelus dromedarius) from Riyadh Province, Saudi Arabia. Parasites \& Vectors 13(1): 1-9.

Alsarraf, M., Mierzejewska, E.J., Mohallal, E.M.E., Behnke, J.M. \& Bajer, A. (2017). Genetic and phylogenetic analysis of the ticks from the Sinai Massif, Egypt, and their possible role in the transmission of Babesia behnkei. Experimental and Applied Acarology 72(4): 415-427.

Ait Lbacha, H., Zouagui, Z., Alali, S., Rhalem, A., Petit, E., Ducrotoy, M.J., Boulouis, H.-J. \& Maillard, R. (2017). "Candidatus Anaplasma camelii" in one-humped camels (Camelus dromedarius) in Morocco: A novel and emerging anaplasma species? Infectious Diseases of Poverty 6(1): 1.

Azeem, T., Tipu, M.Y., Aslam, A., Ahmed, S., Abid, S.A., Iqbal, A., Akhtar, N., Saleem, M., Mushtaq, A. \& Umar, S. (2019). Hematobiochemical disorder in camels suffering from different Hemoparasites. Pakistan Journal of Zoology 51(2): 591596.

Azmat, M., Ijaz, M., Farooqi, S.H., Ghaffar, A., Ali, A., Masud, A., Saleem, S., Rehman, A., Ali, M.M., Mehmood, K., Khan, A. \& Zhang, H. (2018). Molecular epidemiology, associated risk factors, and phylogenetic analysis of anaplasmosis in camel. Microbial Pathogenesis 123: 377384.

Bahrami, S., Tabandeh, M.R. \& Tafreshi, A.R.G. (2017). Prevalence and molecular identification of piroplasmids in Iranian dromedaries (Camelus dromedarius). Journal of Zoo and Wildlife Medicine 48(4): 1026-1030.

Bahrami, S., Hamidinejat, H. \& Tafreshi, A.R.G. (2018). First molecular detection of Anaplasma phagocytophilum in dromedaries (Camelus dromedarius). Journal of Zoo and Wildlife Medicine 49(4): 844. 
Bastos, A.D.S., Mohammed, O.B., Bennett, N.C., Petevinos, C. \& Alagaili, A.N. (2015). Molecular detection of novel Anaplasmataceae closely related to Anaplasma platys and Ehrlichia canis in the dromedary camel (Camelus dromedarius). Veterinary Microbiology 179(3-4): 310-314.

Bekele, M. (2010). An epidemiology study of major camel disease in the Borana Lowland, southern Ethiopia (Drylands Coordination Group Report).

Belkahia, H., Said, M.B., Sayahi, L., Alberti, A. \& Messadi, L. (2015). Detection of novel strains genetically related to Anaplasma platys in tunisian one-humped camels (Camelus dromedarius). Journal of Infection in Developing Countries 9(10): 117-1125.

Dahmana, H., Carette, O., Amanzougaghene, N., Davoust, B., Normand, T., Chik, M., Demoncheaux, J-P., Mulot, B., Fabrizy, B., Scandola, P., Fenollar, F. \& Mediannikov, O. (2019). Great diversity of Piroplasmida in Equidae in Africa and Europe, including potential new species. Veterinary Parasitology: Regional Studies and Reports 18: 100332.

Dahmani, M., Davoust, B., Tahir, D., Raoult, D., Fenollar, F. \& Mediannikov, O. (2017). Molecular investigation and phylogeny of Anaplasmataceae species infecting domestic animals and ticks in Corsica, France. Parasites \& Vectors 10: 302.

de La Fuente, J., Antunes, S., Bonnet, S., Cabezas-Cruz, A., Domingos, A.G., Estrada-Peña, A., Johnson, N., Kocan, K.M., Mansfield, K.L. \& Nijhof, A.M. (2017). Tick-pathogen interactions and vector competence: identification of molecular drivers for tick-borne diseases. Frontiers in Cellular and Infection Microbiology 7: 114.

Elzaki, R.M., Ahmed, S.H. \& Al-Mahish, M.A. (2018). Camel Production in Kingdom of Saudi Arabia: Economic and Environmental Impacts. Fundamental and Applied Agriculture 3: 602-608.
Estrada-Peña, A., Bouattour, A., Camicas, J.L. \& Walker, A.R. (2004). Ticks of domestic animals in the Mediterranean region. A guide to identification of species. Zaragoza: University of Zaragoza (Vol. 131).

Ghafar, M.W. \& Shobrak, M.Y. (2014). Molecular detection and characterization of Anaplasma phagocytophilum, the causative agent of human granulocytic anaplasmosis, in some animals suspected to be competent reservoirs in Taif district, kingdom of Saudi Arabia. Life Science Journal 11(6): art. no. 9, 6369.

General Authority for Statistics 2015. Detailed results of the agriculture census. General Authority for Statistics, Saudi Arabia. pp 406-407.

General Authority for Statistics, 2016. National accounts indicators. General Authority for Statistic, Saudi Arabia. p 11. Hoogstraal, H., Wassef, H. \& Büttiker, W. (1981). Ticks (Acarina) of Saudi Arabia. Fam. Argasidae, Ixodidae. Fauna of Saudi Arabia 3: 25-110.

Ismael, A.B., Swelum, A.A., Khalaf, A.F. \& Abouheif, M.A. (2014). Clinical, haematological and biochemical alterations associated with an outbreak of theileriosis in dromedaries (Camelus dromedarius) in Saudi Arabia. Pakistan Veterinary Journal 34: 209-213.

Li, Y., Yang, J., Chen, Z., Qin, G., Li, Y., Li, Q., Liu, J., Liu, Z., Guan, G., Yin, H., Luo, J. \& Zhang, L. (2015). Anaplasma infection of Bactrian camels (Camelus bactrianus) and ticks in Xinjiang, China. Parasites \& Vectors 8(1): 313.

Li, Y., Li, X., Liu, J., Wang, J., Jia, D., Liu, A., He, Z., Guan, G., Liu, Z., Liu, G., Luo, J. \& Yin, H. (2019). First Report of Theileria Infection of Bactrian Camels (Camelus bactrianus) in Xinjiang, China. Acta Parasitologica 64(4): 923-926.

Jabbar, A., Abbas, T., Saddiqi, H.A., Qamar, M.F. \& Gasser, R.B. (2015). Tick-borne diseases of bovines in Pakistan: major scope for future research and improved control. Parasites \& Vectors 8: 283. 
Khamesipour, F., Doosti, A., Koohi, A., Chehelgerdi, M., Mokhtari-Farsani, A. \& Chengula, A.A. (2015). Determination of the presence of Babesia DNA in blood samples of cattle, camel and sheep in Iran by PCR. Archives of Biological Sciences 67(1): 83-90.

Kumar, S., Stecher, G., Li, M., Knyaz, C. \& Tamura, K. (2018). MEGA X: Molecular Evolutionary Genetics Analysis across computing platforms. Molecular Biology and Evolution 35: 1547-1549.

Lorusso, V., Wijnveld, M., Latrofa, M.S., Fajinmi, A., Majekodunmi, A.O., Dogo, A.G., Igweh, A.C., Otranto, D., Jongejan, F., Welburn, S.C. \& Picozzi, K. (2016). Canine and ovine tick-borne pathogens in camels, Nigeria. Veterinary Parasitology 228: 90-92.

Mazyad, S.A. \& Khalaf, S.A. (2002). Studies on Theileria and Babesia infecting live and slaughtered animals in $\mathrm{Al}$ Arish and El Hasanah, North Sinai Governorate, Egypt. Journal of the Egyptian Society of Parasitology 32(2): 601-610.

Mohammed, A., Sharma, A., Saied, M., Osman, O., Al-Balowi, M., Salih, D. \& Singla, L. (2017). Lack of evidence for infection of camels with tick-borne diseases in Riyadh region, Saudi Arabia. Sudan Journal of Veterinary Research 32: 3940.

Mostafa, O.M. \& Dajem, S.B. (2014). Prevalence of Babesia bovis and $B$. bigemina in animals slaughtered in Abha and Khamis Mushait abattoirs, Aseer, Saudi Arabia, using PCR assay. Research Journal of Pharmaceutical, Biological and Chemical Sciences 5(5): 1233-1237.

Noaman, V. (2018). Molecular detection of novel genetic variants associated to Anaplasma ovis among dromedary camels in Iran. Archives of Razi Institute 73(1): 11-18.

Orkun, Ö., Karaer, Z., Çakmak, A. \& Nalbantoğlu, S. (2014). Identification of tick-borne pathogens in ticks feeding on humans in Turkey. PLoS Neglected Tropical Diseases 8: e3067.
Otranto, D. \& Dantas-Torres, F. (2010). Canine and feline vector-borne diseases in Italy: current situation and perspectives. Parasites \& Vectors 3: 2.

Qablan, M.A., Sloboda, M., Jirků, M., Oborník, M., Dwairi, S., Amr, Z.S., Hořín, P., Lukeš, J. \& Modrý, D. (2012). Quest for the piroplasms in camels: Identification of Theileria equi and Babesia caballi in Jordanian dromedaries by PCR. Veterinary Parasitology 186 (3-4): 456460.

Redwan, E.M., Korim, S., Samra, A., Saad, Y., Amhedar, H.A. \& Uversky, V.N. (2018). Variability of Some Milk-Associated Genes and Proteins in Several Breeds of Saudi Arabian Camels. The Protein Journal 37: 333-352.

Rufino, C.P., Moraes, P.H., Reis, T., Campos, R., Aguiar, D.C., McCulloch, J.A., Meneses, A.M. \& Gonçalves, E.C. (2013). Detection of Ehrlichia canis and Anaplasma platys DNA using multiplex PCR. Vector Borme Zoonotic Disease 13: 846-50.

Hall, T. (2011). BioEdit: An Important Software for Molecular Biology Software Review.

Turaki, U.A., Kumsha, H.A., Biu, A.A. \& Bokko, P.B. (2014). Prevalence of Piroplasmosis amongst local horses in Northeastern Nigeria. IOSR Journal of Agriculture and Veterinary Science 7(12): 04-07.

Salim, B., Alanazi, A.D., Omori, R., Alyousif, M.S., Alanazi, I.O., Katakura, K. \& Nakao, R. (2019). Potential role of dogs as sentinels and reservoirs for piroplasms infecting equine and cattle in Riyadh City, Saudi Arabia. Acta Tropica 193: 78-83.

Sazmand, A., Harl, J., Eigner, B., Hod•ić, A., Beck, R., Hekmatimoghaddam, S., Mirzaei, M., Fuehrer, H.-P. \& Joachim, A. (2019). Vector-borne bacteria in blood of camels in Iran: New data and literature review. Comparative Immunology, Microbiology and Infectious Diseases 65: $48-53$. 
Selmi, R., Dhibi, M., Ben Said, M., Ben Yahia, H., Abdelaali, H., Ameur, H., Baccouche, S., Gritli, A. \& Mhadhbi, M. (2019). Evidence of natural infections with Trypanosoma, Anaplasma and Babesia spp. in military livestock from Tunisia. Tropical Biomedicine 36(3): 742-757.

Selmi, R., Ben Said, M., Dhibi, M., Ben Yahia, H., Abdelaali, H. \& Messadi, L. (2020). Genetic diversity of groEL and msp4 sequences of Anaplasma ovis infecting camels from Tunisia. Parasitology International 74: 101980.

Sharifiyazdi, H., Jafari, S., Ghane, M., Nazifi, S. \& Sanati, A. (2017). Molecular investigation of Anaplasma and Ehrlichia natural infections in the dromedary camel (Camelus dromedarius) in Iran. Comparative Clinical Pathology 26(1): 99-103.
Wall, R. \& Shearer, D. (2001). Veterinary Entomology 2nd edition, Blackwell Science, London, United Kingdom, pp. 64-77.

Yuasa, Y., Hsu, T.-H., Chou, C.-C., Huang, C.C., Huang, W.-C. \& Chang, C.-C. (2012). The comparison of spatial variation and risk factors between mosquito-borne and tick-borne diseases: Seroepidemiology of Ehrlichia canis, Anaplasma species, and Dirofilaria immitis in dogs. Comparative Immunology, Microbiology and Infectious Diseases 35: 599-606. 